\title{
Xylodiol, a New Atisane Diterpenoid from Xylopia Langsdorffiana St.-Hil. \& Tul. (Annonaceae)
}

Josean Fechine Tavares ${ }^{\mathrm{a}}$, Marianna Vieira B. Silva ${ }^{\mathrm{a}}$, Karine F. Queiroga ${ }^{\mathrm{a}}$, Margareth F. F. Melo Diniz ${ }^{\mathrm{a}}$, José M. Barbosa Filho ${ }^{\mathrm{a}}$, Marcela Haun ${ }^{\mathrm{b}}$, Patrícia S. Melo ${ }^{\mathrm{b}, \mathrm{c}}$, and Marcelo Sobral da Silva ${ }^{\mathrm{a}}$

${ }^{a}$ Laboratório de Tecnologia Farmacêutica, Universidade Federal da Paraíba, CP 5009, João Pessoa, PB 58051-970, Brazil

b Departamento de Bioquímica, Instituto de Biologia, Universidade Estadual de Campinas, CP 6109, Campinas, SP 13083-970, Brazil

${ }^{c}$ Faculdades Integradas Metropolitanas de Campinas, Rua Abolição, $n^{\circ}$ 1827, Swift, Campinas, SP, Brazil

Reprint requests to Dr. Marcelo Sobral da Silva. E-mail: marcelosobral@ltf.ufpb.br

Z. Naturforsch. 2007, 62b, 742-744; received November 20, 2006

Two diterpenes were isolated from the leaves of Xylopia langsdorffiana, the new ent-atisane$7 \alpha, 16 \alpha$-diol named xylodiol (1) and the known 8 (17),12E,14-labdatrien-18-oic acid (2). The structures of these isolates were deduced by spectroscopic data interpretation. Compound $\mathbf{2}$ was less toxic than xylodiol on V79 cells and hepatocytes.

Key words: Xylopia langsdorffiana, Annonaceae, Atisane, Labdane, Cytotoxicity

\section{Introduction}

The genus Xylopia (Annonaceae) comprises about 160 species [1]. Various species of this genus are used in folk medicine for rheumatism [2] and as antimicrobial agents [3]. Kaurane, labdane and trachylobanetype diterpenes are encountered in this genus $[4,5,6]$. Atisane diterpenes are rare in the Annonaceae family, having been recorded only in Xylopia aromatica [6]. In addition, this group of compounds has not been studied biologically to a large extent as yet. However, other atisane-type diterpenes isolated from different species show anti-HIV [7] and insecticidal activities and are cytotoxic to mouse P388 leukemia cells [8].

Xylopia langsdorffiana St-Hil. \& Tul. is a tree, 5$7 \mathrm{~m}$ high, and popularly known in Northeast Brazil as "pimenteira da terra" [3]. As part of our continuing investigations of bioactive molecules from plants of Brazil, we now report on the isolation from the $X$. langsdorffiana leaves and the characterisation of a new atisane named xylodiol (1) and the known labdane (2) diterpene as well as their cytotoxicity assays against V79 fibroblasts and hepatocytes. Vasorelaxant and hypotensive activities were reported recently for 2 [9].

In vitro systems provide important tools to enhance our understanding of the hazardous effects of novel pharmacological agents. Most of the attention has been focused on cytochrome P450s (CYPs), the primary enzyme superfamily involved in the metabolism of a broad range of drugs in different species, including man [10]. The cytotoxicity of metabolites produced by hepatic biotransformation is frequently assessed in cultured fibroblasts and hepatocytes [11].

\section{Experimental Section}

General procedures

Melting points were measured in a Geahaka model PF1500 version 1.0 apparatus and are uncorrected. Optical rotations were determined on a ADP 220 polarimeter, Bellingham-Stanley Ltd. IR spectra were obtained in $\mathrm{KBr}$ disks in a Bomem model MB 100M series spectrophotometer. ${ }^{1} \mathrm{H}$ and ${ }^{13} \mathrm{C}$ NMR spectra were obtained with a Bruker DRX-500 spectrometer, using $\mathrm{CDCl}_{3}$ as solvent. HREIMS were recorded in a VG-AutoSpec spectrometer, using a direct insertion probe and electron impact at $70 \mathrm{eV}$. The mass spectra were obtained on a Hewlett-Packard 5971 mass spectrometer by electron impact ionisation at $70 \mathrm{eV}$.

\section{Plant material}

The leaves of Xylopia langsdorffiana were collected in the municipality of Cruz do Espírito Santo, State of Paraíba, in July 2002. The plant material was identified by Prof. Maria de Fátima Agra, Head of the Botany Section of the Labo- 
ratório de Tecnologia Farmacêutica Prof. Delby Fernandes de Medeiros (LTF). A voucher specimen (AGRA 5541) is deposited at the Herbário Prof. Lauro Pires Xavier (JPB) of the Universidade Federal da Paraíba.

\section{Extraction and isolation}

Dried leaves of $X$. langsdorffiana $(2 \mathrm{~kg})$ were exhaustively extracted with $95 \% \mathrm{EtOH}$ at r.t. Removal of the solvent under reduced pressure in a rotary evaporator yielded a dark green extract (140 g), which was partitioned successively with hexane, $\mathrm{CHCl}_{3}$ and EtOAc to yield 20, 16 and $12 \mathrm{~g}$ of crude residues, respectively. The hexane fraction was subjected to column chromatographic separation with silica gel and eluted with hexane/ethyl acetate in an increasing polarity gradient. Fractions with similar TLC were combined. Fractions $13-28$ were purified by preparative TLC over silica gel using hexane/EtOAc $(8: 2)$ to afford the diterpenoid $1(72 \mathrm{mg})$ and fractions $29-40$ were purified in the same way using hexane/EtOAc $(7: 3)$ to afford the diterpenoid 2 (81 mg).

\section{Biological assay}

Xylodiol (1) and compound 2 were tested for in vitro cytotoxic activity against V79 cells and rat hepatocytes using the nucleic acid content (NAC), tetrazolium reduction (MTT) and neutral red uptake (NRU) assays, as described previously [17]. Hepatocytes were isolated from 2 months old Wistar male rats $(200-250 \mathrm{~g})$ by a two-step collagenase perfusion method [18].

\section{Ent-atisan-7 $\alpha, 16 \alpha$-diol or xylodiol (1)}

Obtained as a crystalline solid, m.p. $108-111{ }^{\circ} \mathrm{C}$. $[\alpha]_{\mathrm{D}}^{25}=+46\left(c=0.19, \mathrm{CHCl}_{3}\right) .-\mathrm{IR}(\mathrm{KBr}): v=3372,3325$, 2985, $1130 \mathrm{~cm}^{-1}$. - HREIMS: $\mathrm{m} / z=306.2017\left[\mathrm{M}^{+}\right]$, compatible with the molecular formula $\mathrm{C}_{20} \mathrm{H}_{34} \mathrm{O}_{2}$.

\section{8 (17),12E,14-labdatrien-18-oic acid (2)}

Obtained as a crystalline solid, m.p. $139-141{ }^{\circ} \mathrm{C}$. $[\alpha]_{\mathrm{D}}^{27}=-43\left(c=0.19, \mathrm{CHCl}_{3}\right) .-\mathrm{IR}(\mathrm{KBr}): v=3.083,2.934$, 2.870, 1.692, 1.643, 1.276, $901 \mathrm{~cm}^{-1}$. - EIMS (EI): $\mathrm{m} / \mathrm{z}$ $(\%)=302.6\left[\mathrm{M}^{+}\right], 119(100), 122(48), 147$ (78), $159(45)$, 161 (29), 176 (55), 242 (10), compatible with the molecular formula $\mathrm{C}_{20} \mathrm{H}_{28} \mathrm{O}_{2}$.

\section{Results and Discussion}

Compound 1 was obtained as a crystalline solid, m. p. $108-111{ }^{\circ} \mathrm{C}$ and $[\alpha]_{\mathrm{D}}^{25}=+46$ in chloroform. The HREIMS of $\mathbf{1}$ showed a molecular ion peak at $\mathrm{m} / \mathrm{z}=306.2017$, compatible with the molecular formula $\mathrm{C}_{20} \mathrm{H}_{34} \mathrm{O}_{2}$, having 4 degrees of unsaturation in the molecule. The IR spectrum showed absorptions at 3372 and $3325 \mathrm{~cm}^{-1}$, characteristic of hydroxyl
Table 1. NMR data for xylodiol (1).

\begin{tabular}{|c|c|c|c|c|c|}
\hline \multirow{2}{*}{$\mathrm{C}$ atom } & \multicolumn{2}{|c|}{ HMQC } & \multirow[b]{2}{*}{ HMBC } & \multicolumn{2}{|c|}{${ }^{1} \mathrm{H} \times{ }^{1} \mathrm{H}$} \\
\hline & $\overline{\delta^{13} \mathrm{C}^{\mathrm{a}}}$ & $\delta^{1} \mathrm{H}^{\mathrm{a}}$ & & $\overline{\mathrm{COSY}}$ & $\overline{\text { NOESY }}$ \\
\hline \multirow[t]{2}{*}{$\overline{1}$} & 42.0 & $1.45(\mathrm{~m})$ & & & \\
\hline & & $1.25(\mathrm{~m})$ & & & \\
\hline \multirow[t]{2}{*}{2} & 18.1 & $1.68(\mathrm{~m})$ & & & \\
\hline & & $1.45(\mathrm{~m})$ & & & \\
\hline \multirow[t]{2}{*}{3} & 39.1 & $1.66(\mathrm{~m})$ & & H-3 & \\
\hline & & $0.94(\mathrm{~m})$ & & & \\
\hline 4 & 37.7 & - & & & \\
\hline 5 & 47.3 & $1.42(\mathrm{~m})$ & $\mathrm{H}-1$ & & \\
\hline \multirow[t]{2}{*}{6} & 26.8 & $1.71(\mathrm{~m})$ & H-7 & H-6 & \\
\hline & & $1.67(\mathrm{~m})$ & & & \\
\hline 7 & 73.8 & 3.43 (broad) & H-5 / H-9 / H-15 & & $\mathrm{H}-14$ \\
\hline 8 & 32.5 & - & & & \\
\hline 9 & 46.0 & $1.59(\mathrm{~m})$ & $\mathrm{H}-13$ / H-11 & & \\
\hline 10 & 37.7 & - & & & \\
\hline \multirow[t]{2}{*}{11} & 22.4 & $1.77(\mathrm{~m})$ & & & \\
\hline & & $1.53(\mathrm{~m})$ & & & \\
\hline 12 & 38.1 & $1.63(\mathrm{~m})$ & $\mathrm{H}-13 / \mathrm{H}-11$ & & \\
\hline \multirow[t]{2}{*}{13} & 23.5 & $2.02(\mathrm{~m})$ & & H-13 & \\
\hline & & $1.19(\mathrm{~m})$ & & & \\
\hline \multirow[t]{2}{*}{14} & 26.7 & $1.70(\mathrm{~m})$ & & H-14 & \\
\hline & & $0.99(\mathrm{~m})$ & & & \\
\hline \multirow[t]{2}{*}{15} & 51.3 & $1.78(\mathrm{~m})$ & H-14 & & \\
\hline & & $1.30(\mathrm{~m})$ & & & \\
\hline 16 & 72.2 & - & H-11 / H-15 & & \\
\hline 17 & 30.5 & $1.35(\mathrm{~s})$ & & & $\mathrm{H}-7$ \\
\hline 18 & 33.1 & $0.91(\mathrm{~s})$ & & & \\
\hline 19 & 21.6 & $0.86(\mathrm{~s})$ & & & \\
\hline 20 & 13.4 & $0.99(\mathrm{~s})$ & H-5 & & \\
\hline
\end{tabular}

Table 2. Cytotoxicity of xylodiol (1) and compound 2 on V79 cells and rat hepatocytes.

\begin{tabular}{llcclll}
\hline \multirow{2}{*}{ Compound } & \multicolumn{2}{c}{$I C_{50}(\mu \mathrm{mol})$} & & & \\
& MTT & NRU & NAC & MTT & NRU & NAC \\
& 112 & 56 & 70 & 139 & - & - \\
Xylodiol & 250 & 138 & 220 & - & - & - \\
\hline
\end{tabular}

(-): Viability similar to control cells until $300 \mu \mathrm{mol}$.

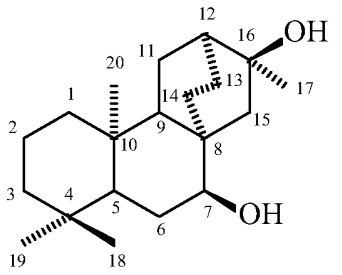

1

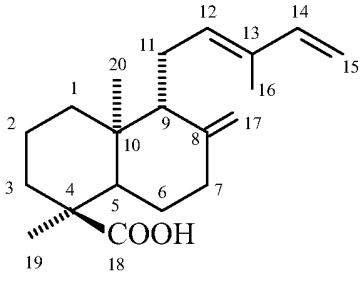

2
Fig. 1. Diterpenoids $\mathbf{1}$ and $\mathbf{2}$ from Xylopia langsdorffiana.

groups. The presence of four methyl, eight methylene and four methine groups and four quaternary carbons was supported by the DEPT and HMQC (Table 1). Furthermore, by comparison of the NMR data of $\mathbf{1}$ with 
those of similar structures $[12,13]$ we concluded that it belongs to the ent-atisane diterpene compound class. The location of the hydroxyl groups at C-7 and C-16 was deduced from the HMBC. Correlations between the protons at $\delta_{\mathrm{H}}=1.42(\mathrm{H}-5), 1.59(\mathrm{H}-9)$, and 1.78 $(\mathrm{H}-15)$, and the oxygenated carbon at $\delta_{\mathrm{C}}=73.8$ allowed the location of one hydroxyl at C-7. The other hydroxyl group was located at $\mathrm{C}-16$ due to the correlations between $\delta_{\mathrm{H}}=1.77(\mathrm{H}-11), \delta_{\mathrm{H}}=1.30(\mathrm{H}-15)$, and the carbon at $\delta_{\mathrm{C}}=72.2$. The $\alpha$ orientation of the hydroxyl group at $\mathrm{C}-7$ was deduced by the presence of a broad signal for $\mathrm{H}-7$ and comparison with literature data [14]. The NOESY spectrum was also used to establish the relative stereochemistry at this center. The one- and two-dimensional ${ }^{1} \mathrm{H} /{ }^{13} \mathrm{C}$ NMR data are shown in Table 1. Based on the above evidence, the relative stereochemistry of the carbons at C-7 and $\mathrm{C}-16$ is established. Although we have not determined the absolute stereochemistry, the molecule is represented with $\alpha$ orientation for the hydroxyl groups at C-7 and C-16. Therefore, the structure of compound $\mathbf{1}$, a new diterpene, was proposed as ent-atisan-7 $\alpha, 16 \alpha$ diol, named xylodiol (Fig. 1).

Compound 2 was obtained as a crystalline solid (m. p. $139-141^{\circ} \mathrm{C}$ ). The EIMS of 2 showed a molecular ion peak at $m / z=302.26$, compatible with the molecular formula $\mathrm{C}_{20} \mathrm{H}_{28} \mathrm{O}_{2}$, with 7 degrees of unsaturation. The molecular structure of $\mathbf{2}$ was confirmed by the ${ }^{1} \mathrm{H} /{ }^{13} \mathrm{C}$ NMR $1 \mathrm{D}$ and 2D spectra, and agreed with that previously reported for 8 (17),12E,14-labdatrien18-oic acid [15].

The biological activities of $\mathbf{1}$ and $\mathbf{2}$ are summarised in (Table 2). Compound $\mathbf{2}$ induced no significant suppression on the viability of hepatocytes at concentrations up to $300 \mu \mathrm{mol}$. No cytotoxicity was detected in hepatocytes after treatment with up to $300 \mu \mathrm{mol}$ of xylodiol evaluated by NRU and NAC assays, however it was determined an $I C_{50}$ value of $139 \mu \mathrm{mol}$ evaluated by MTT reduction assay. These results indicate that this compound is more toxic to mitochondria than the others endpoints measured (NRU and NAC). The different effects observed on V79 cells and rat hepatocytes, especially for xylodiol in the NRU and NAC tests, suggest that the P450-mediated biotransformation of such diterpenes may lead to the formation of less toxic metabolites. In a previous investigation, $x y-$ lodiol exhibited an $I C_{50}$ value of $40 \mu \mathrm{mol}$ against the K562 human leukemia cell line [16].

\section{Acknowledgement}

This work was supported by FAPESP, CNPq, CAPES and CENAUREM / UFC.
[1] P. J. M. Maas, H. M. V. Kamer, L. Junikka, R. M. Silva, H. Rainer, Rodriguésia 2001, 80, $65-98$.

[2] C. M. Agelita, B.C. Betânia, B. O. Alaíde, C. B. Fern ao, Fitoterapia 2001, 72, 40-45.

[3] M. P. Corrêa in Dicionário das Plantas Úteis do Brasil e das Exóticas Cultivadas, Vol. 4, IBDF, Ministério da Agricultura, Rio de Janeiro, 1984, p. 315.

[4] D. F. Faulkner, V. Lebby, P. G. Waterman, Planta Med. 1985, 4, 354.

[5] N.C. Andrade, J.M. Barbosa-Filho, M.S. Silva, E. V. L. da-Cunha, J. G. S. Maia, Biochem. Syst. Ecol. 2004, 32, $1055-1058$.

[6] M. P. L. Morais, N. F. Roque, Phytochemistry 1988, 27, $3205-3208$.

[7] I. C. Sun, Y. Kashiwada, S. L. Morris-Natschke, K. H. Lee, Curr. Top. Med. Chem. 2003, 3, 155-169.

[8] N. B. Perry, E. J. Burgess, S.-H. Baek, R. T. Weavers, Org. Lett. 2001, 3, $4243-4245$.

[9] A.P. Oliveira, F. F. Furtado, M. S. Silva, J. F. Tavares, R. A. Mafra, D. A. M. Araújo, J.S. Cruz, I. A. Medeiros, Vasc. Pharmacol. 2006, 44, $338-344$.

[10] F. Zucco, I. de Angelis, E. Testai, A. Stammati, Toxicol. in Vitro 2004, 18, 153 - 163.
[11] P. S. Melo, H. M. M. Cavalcante, J. M. Barbosa-Filho, M. F. F. M. Diniz, I. A. Medeiros, M. Haun, Toxicol. Lett. 2003, 142, $143-151$.

[12] T. Konishi, K. Yamazoe, M. Kanzato, T. Konoshima, Y. Fujiwara, Chem. Pharm. Bull. 2003, 51, $1142-$ 1146.

[13] J. St. Pirek, J. Nat. Prod. 1984, 47, 822 - 827.

[14] J. F. Tavares, K. F. Queiroga, M. V. B. Silva, M. F. F. M. Diniz, J. M. Barbosa-Filho, E. V. L. da-Cunha, C. A. Simone, J. X. Araújo-Júnior, P. S. Melo, M. Haun, M. S. Silva, J. Nat. Prod. 2006, 69, 960-962.

[15] F. Bohlmann, J. Jakupovic, R. M. King, H. Robinson, Phytochemistry 1980, 19, 863.

[16] M. V. B. Silva, M.C. Anazetti, J.F. Tavares, M. S. Silva, M. F. F. M. Diniz, P. S. Melo, M. Haun, Braz. J. Pharm. Sci. 2005, 41, 481.

[17] P. S. Melo, N. Durán, M. Haun, Hum. Exp. Toxicol. 2002, 21, 281-288.

[18] C. Guguen-Guillouzo, A. Guillouzo, in Isolated and Cultured Hepatocytes, (Eds.: A. Guillouzo, C. GuguenGuillouzo), Les Editions INSERM and John Libbey, Eurotext, Paris, 1986, pp. 1-12. 